\title{
Management Accounting Information in Vietnamese Small and Medium Sized Enterprises
}

\author{
Thi Tu Oanh Le ${ }^{1}$, Thi Ngoc Bui ${ }^{1} \&$ Manh Dung Tran ${ }^{2}$ \\ ${ }^{1}$ University of Labor and Social Affairs, Vietnam \\ ${ }^{2}$ National Economics University, Vietnam \\ Correspondence: Manh Dung Tran, Room No. 202, A14, Living quarter of National Economics University, Hai Ba \\ Trung District, Hanoi, Vietnam.
}

Received: November 8, 2017

Accepted: November 22, 2017

Online Published: November 27, 2017

doi:10.5430/afr.v7n1p130

URL: https://doi.org/10.5430/afr.v7n1p130

\begin{abstract}
The small and medium-sized enterprises (SMEs) in Vietnam play an increasingly important role in the economy by the amount (representing $97.7 \%$ of Vietnam firms), contribute economic development and create more employment opportunities. However, because of economic crisis, financial downturn, unhealthy competitions, free trade agreements and others, the number of SMEs recently is downsizing in firm size, human resources and more and more SMEs go bankruptcy in the context of Vietnam. This situation may be due to the enterprise use ineffective management accounting tools.

This article reviews and assesses the creation and use of management accounting information which has an important part to play with respect to planning, decision-making, monitoring and controlling of the activities of SMEs in Vietnam. Data collected from a posted survey of five enterprises with twenty two interviews of directors, chief accountants and management accountants. The results show that management accounting information has not really been interested from managers and accountants. Management accounting information is weak in quantity and poor in quality; administrators are operating firms primarily based on personal experiences. Therefore, management accounting information has not been promoted in the management, monitoring and decision making of SMEs in Vietnam. The addition of management accounting knowledge for managers and accountants is necessary for development of SMEs.
\end{abstract}

Keywords: Accounting information, Management accounting, Vietnam

\section{Introduction}

The small and medium-sized enterprises (SMEs) in Vietnam play an increasingly important role in the economy by the amount and the contribution of economic indicators and creating employment opportunity. According to the General Statistics Office (2016), the number of SMEs is 324,377 enterprises at 31/12/2016, comprises approximately $97.7 \%$ of all Vietnam firms. When engaged in international trade, SMEs suffer from the fierce competition for survival and development. The lack of adequate working capital, poor management skill and unscientific finance management practices cause the collapse or discontinuity of business. The number of enterprises is downsizing, winding up, and increasing bankruptcy. According to the General Statistics Office (2015), the number of firms fled to the date $30 / 06 / 2015$ is about 175,000 firms, focusing on small and medium-sized enterprises. In addition to objective reasons from the general economic downturn, the subjective reasons from the business may be due management accounting information may not be interested in and underutilized. We need conducting the research for clarifying this issue.

The purpose of this research is to investigate the management accounting information generated and used for planning, decision making and controlling in small and medium - sized manufacturing enterprises in Vietnam. Management accounting information that provides for managers and decision makers from the collection, measurement, analysis and evaluation in order to give sound decision making on the side of stakeholders including management.

The research questions were posed as (i) what contents of management accounting information can be used by manager in SMEs in Vietnam?; (ii) how management accounting information was prepared and provided?; (iii) what are the benefits of a management accounting information system to managers' decision making? 


\section{Literature Review}

SMEs play a particularly important role in the economy in most countries in the world. The topic of management accounting information employed in the enterprise was more interested in scholars, however, there is a dearth of studies regarding the use of management accounting among SMEs. Studies of management accounting among SMEs conducted by by Hopper et al. (1999), Jarvis et al. (2000), Marriott et al. (2000); Reid \& Smith (2002), and Sousa et al. (2006) are still fragmented and focused on a different aspects of management accounting. Mitchell \& Reid (2000) argued that the expertise and capacity to innovate in management accounting is less likely to exist. A number of studies have investigated the adoption of management accounting practices in developed countries such as in Japan, US, UK, other Europe countries and Australia (Drury et al., 1993; Abdel-Kader \& Luther, 2006; Shields et al, 1991; Scarbrough et al., 1991; Chenhall \& Langfield-Smith, 1998; Wijewardena \& De Zoysa, 1999). In developing countries, comparable empirical researches did not emerge until the mid-1990s such as studies of Firth (1996); Ghosh \& Chan (1997); Joshi (2001); Phadoongsitthi (2003); and El-Ebaishi et al. (2003). While these studies found the real management accounting practices in larger firms, studies in smaller firms or SMEs are still in a shortage.

Currently, many different views of the role of management accounting in enterprises, especially for SMEs, it can be divided into 2 schools as

\section{First, promotion of the role of management accounting in SMEs is not interested}

Beginning 1987, Johnson \& Kaplan (1987) claimed that management accounting had not changed since the early part of the twentieth century, it had lost relevance by failing to provide relevant information for managerial needs. In response to these concerns, a range of remarkable innovations in management accounting has emerged. The more contemporary management accounting combines both financial and non-financial information and take an explicit strategic focus (Chenhall \& Langfield-Smith, 1998). This can be seen, for example in the design of activity based costing (ABC), strategic management accounting (SMA) and contemporary performance measurement systems such as balanced scorecard (BSC). With this regard, a lot of empirical studies have begun to investigate the current practices of management accounting in specific enterprises.

Drury et al. (1993) asserted that there have been allegations about a lack of relevance of management accounting to management needs, especially in modern manufacturing, and about the existence of a gap between management accounting theory as portrayed in textbooks and management accounting in practice. Drury et al. (1993) found that small businesses generally reported using more simplistic techniques, and the use of techniques such as indicators (ratios), market research and advanced quantitative techniques. The primary contents of these critiques were that management accounting fails to respond the developments in the technological and competitive environment, with the result that internal accounting information is frequently inaccurate and misleading. Similarly, Gunasekaran et al. (1999) UK found that ABC has received little attention from SMEs in spite of the fact that it has an important role to play in improving the competitiveness of SMEs.

In Japan, the survey of cost accounting in SMEs was conducted by Hopper et al. (1999) indicated that costing systems in Japanese SMEs were similar to those of larger Japanese firms. Costing systems and cost management practices though not uniform, emphasized simple routine accounting. They were not used extensively for decision-making or performance evaluation. However, sophisticated detailed processes of cost management, which often centered on engineering and quality control, were the norms.

McChlery et al. (2004) investigated the scope of the financial management systems (including MAPs) operating within small firms. They found that management accounting systems have not been employed in management. They also found that smaller firms were most likely to be dissatisfied with their management accounting systems. Sousa et al. (2006) determined the financial measures were the most widely used, while management accounting system was regarded less important and was less used.

\section{Second, the role of management accounting in SMEs is interested}

In contrast, the other school demonstrates the role of management accounting for enterprises. Typical among them was Friedley (1956) and Smith (1962) focused research in the steel firms. They state that in order to control costs, the cost estimates are prepared for each product and each department but are limited in the scope of expenses that administrators can control. To evaluate the results of implementation and timely adjustment, cost estimate reports should be prepared monthly. Through analysis of the difference between actual costs and estimated monthly costs, managers can determine the cause of the fluctuations and changes (Smith, 1962; Hoque at al, 2000). Besides analytical methods of cost differences, Smith (1962) proposes a method for analyzing fluctuations in costs by graphic. 
In US, Demong \& Croll (1981) concluded that although most US small firms started without a cost accounting system, its usefulness became quickly apparent to the owner and managers. A well-designed cost accounting system with its budgets, standard costs and break-even analyses will enable managers to make better economic decisions. Demong \& Croll (1981) suggested all firms in the same industry were not required the same things from a cost accounting system. The larger firms need a more sophisticated system to enable them to make frequent decisions on the prices and costs of their products. A smaller firm may only needs a basic budget and some standard cost figures for their more infrequent pricing and cost decisions. In any cases, all firms should have basic cost accounting systems with budgets and standard costs used for planning and controlling. This or any system should be easy to use, understand and maintain. In addition, it should be flexible and cost effective.

The role of management accounting was confirmed in a study of Hopper et al. (1999) in their research among Japanese SMEs, argued that a failure to adopt management accounting practices whether they have other ways to control costs quite effective. This finding is consistent with the results of Reid \& Smith (2002) who argued that efficient information processing plays a vital role in successful smaller enterprises.

Following the study highlighted the role of management accounting, Reid \& Smith (2002) found that only a minority of small firms, typically around a third, set budgets; that payback was the most frequently applied investment appraisal technique, and that the management accounting system (MAS) in a small firm has a significant effect on the operation and performance of the business. The impact of the MAS was greatest in those firms struggling to survive where it can be employed to monitor finances daily and help to identify trends in key variables.

Nandan (2010) argued that larger firms also require adequate and sophisticated management accounting techniques and systems to better manage scare resources and enhance the firm's values. Although SMEs may have some constraints in utilizing full management accounting practices due to their relatively small size and limited resources, like larger firms SMEs face similar forms of complexities, uncertainties and are more prone to failures. Therefore, the need for strategic, accurate and reliable managerial information which is largely provided by management accounting system is equally significant for SMEs. In this regard, management accounting practices assume a potentially important tool for management of SMEs.

In Vietnam, the study focused on the tendency to enhance the role of management accounting. Management accounting research was undertaken since the 1990s, typically Nguyen (1995), Pham (1997) discussed the issue of completeness of Vietnamese accounting. These two authors initially stated the role of management accounting but did not examine particular content types. Pham (2002) focused on the management accounting report systems. Tran (2002) launched the idea of integration of financial and management accounting systems. Inheriting these views, Le (2002) has developed the role of management accounting and management accounting in relation to the cost analysis.

The trend research on cost management accounting are thriving in the studies of Dinh (2003), Duong (2004), Tran (2007), Pham (2007), and Mac (2007). These papers focused on the proposed solutions to control costs by separating costs accurately into fixed and variable elements. The results show that the separation of estimated costs in the relationship with the activity level is necessary, but these costs should be disclosed into fixed and variable elements, from that analyzing cost of changes and determining the reasons for increasing and deceasing costs.

In short, a lot of studies in management accounting with many different subjects, domains and scopes are conducted. However, while these studies found the real management accounting practices in larger firms, studies in smaller firm or SMEs is still in shortage. In Vietnam, the small and medium-sized enterprises (SMEs) play an increasingly important role in the economy by the amount and the contribution of economic indicators and creating employment opportunity should be focusing on research to promote the role of SMEs in the economy. Regarding the content issues, most of the research on methods to control the cost within a business, do not have any research about: What contents of management accounting information are used by managers in SMEs in Vietnam? How management accounting information was prepared and provided? What are the benefits of a management accounting information system to managers' decision making?

\section{Research Methodology}

\subsection{Case Study Approach}

A grounded theory approach is employed with case studies being the main research method. Reasons for choosing this method are that we have not found a consistent theoretical framework relating to this issue, and management accounting information within an entity is sensitive and confidential information, and very difficult to exploit on a large scale. 
A survey was administered to five firms in SMEs in the area of Hanoi, Vietnam which was introduced by friends and personnel relations. These firms belong to manufacturing sector, which have been in business between 8 to 14 years. These firms satisfy the requirements in Decree No. 56/2009/CP with the total capital lower than 100 billion Vietnamese dong and less 300 employees. The enterprise aggregated according to the criteria such as type of enterprise, the number of years that the business had been in operation, total capital, the number of employees, number of owners, manufacturing activities, production processes, locations and markets. Table 1 presents the details information.

Table 1. Profile of the Interviewed Firm Sample

\begin{tabular}{|c|c|c|c|c|c|}
\hline Profile of firms & Firm 1 & Firm 2 & Firm 3 & Firm 4 & Firm 5 \\
\hline 1. Type of firms & joint venture & joint stock & Limited & Limited & Limited \\
\hline 2. Years of operations & 2005 & 2004 & 2005 & 2001 & 2008 \\
\hline 3. Total capital (billions) & 70 & 60 & 30 & 100 & 50 \\
\hline 4. Number of employees & 200 & 80 & 150 & 300 & 40 \\
\hline 5. Number of owners & 2 & 2 & 1 & 3 & 1 \\
\hline 6. Manufacturing activities & $\begin{array}{l}\text { all kinds of } \\
\text { pots and pans }\end{array}$ & Kid's toys & Garments & $\begin{array}{l}\text { Pharmaceuticals } \\
\text { and cosmetics }\end{array}$ & $\begin{array}{l}\text { wood } \\
\text { industry }\end{array}$ \\
\hline 7. Production processes & Processes & Processes & Orders & Processes & Orders \\
\hline 8. Locations & $\begin{array}{ll}\text { Quoc } & \text { Oai } \\
\text { district } & \end{array}$ & $\begin{array}{l}\text { Hoang Mai } \\
\text { district }\end{array}$ & $\begin{array}{l}\text { Cau Giay } \\
\text { district }\end{array}$ & Cau Giay district & $\begin{array}{l}\text { Dong } \\
\text { district }\end{array}$ \\
\hline 9. Markets & $\begin{array}{l}\text { Domestic } \\
\text { (Agency) }\end{array}$ & Domestic & $\begin{array}{l}\text { Domestic, } \\
\text { Export }\end{array}$ & Domestic, Export & $\begin{array}{l}\text { Domestic, } \\
\text { Export }\end{array}$ \\
\hline
\end{tabular}

We have conducted twenty two in-depth interviews with the directors and chief accountants, management accountants for determining the management accounting information provided and used within a company as well as the real reasons of this situation. Management accountants are persons who are responsible for collecting and providing requested information by the directors to perform operations, controlling and making decisions. Table 2 presents the detail information about managers (directors) and accountants.

Table 2. Information of Interviewees of the Sample

\begin{tabular}{|c|c|c|c|c|c|c|}
\hline Information & Firm 1 & Firm 2 & & Firm 3 & Firm 4 & Firm 5 \\
\hline \multicolumn{7}{|l|}{ DIRECTOR } \\
\hline 1. Gender & Male & Male & & Male & Male & Male \\
\hline 2. Age & 45 & 37 & & 37 & 42 & 41 \\
\hline 3. Qualifications & Bachelor & Bachelor & & $\begin{array}{l}\text { High school } \\
\text { diploma }\end{array}$ & Bachelor & Master \\
\hline $\begin{array}{l}\text { 4. Having been } \\
\text { trained in accounting }\end{array}$ & Yes & No & & No & No & Yes \\
\hline $\begin{array}{l}\text { 5. Income per month } \\
\text { (million) }\end{array}$ & 50 & 40 & & 0 & 30 & 0 \\
\hline \multicolumn{7}{|c|}{ MANAGEMENT ACCOUNTING } \\
\hline 1. Quantity & 6 & 2 & & 2 & 7 & 4 \\
\hline 2. Gender & $\begin{array}{l}01 \text { Male, } \\
05 \text { Female }\end{array}$ & Female & & Female & Female & Female \\
\hline 3. Age & $20-40$ & $32-36$ & & $30-31$ & $23-37$ & $23-36$ \\
\hline 4. Qualifications & $\begin{array}{l}\text { 01 Diploma; } 05 \\
\text { Bachelor }\end{array}$ & $\begin{array}{l}\text { 01Doctor; } \\
\text { Master }\end{array}$ & 01 & Bachelor & $\begin{array}{l}\text { Bachelor, } \\
\text { CPA }\end{array}$ & Bachelor \\
\hline 5. Experience & $2-15$ years & 4 years & & 3-4 years & $1-15$ years & 2-12 years \\
\hline 6. Skills & Inactive & $\begin{array}{l}\text { Listening, } \\
\text { creactive }\end{array}$ & & Agile Proactive & $\begin{array}{l}\text { Agile Proactive, } \\
\text { Hard-working }\end{array}$ & Agile Inactive \\
\hline
\end{tabular}


All managers are male, aged 37-45; 01 manager graduated from high school, 03 managers have university degrees and 01 manager has international master's degree; 2 of 5 managers have been trained in accounting; 02 enterprises have the owners who are not to be paid.

There are from 2 of 7 management accountants, with 01 male, the rest are female, aged 20-37. The qualification of accountant including 01 doctor, 01 masters, 01 person has CPA, 01 diploma and universities remaining. Work experiences of accountants are from 01 to 15 years.

An informational interview always adheres to the objectives and the research questions in order to know how each company supplies and uses management accounting information. We outline some basic questions for interviewing. We take note and record the interviews. After interviewing, we set up a situation of description, returning to the interviewees to clarify the information, modify if found out differences.

\subsection{Data Analysis}

Steps in the data analysis process are conducted as below:

First, step 1: gathering data into one summary excel file according to the given basic questions. The flexible answers were put into one section for encoding later.

Second, step 2: (i) viewing the entire data file; (ii) reviewing to find the key word or phrase, the same content in the interviews, compiling and assigning classification criteria (named groups). The interviews with the same content are put into one cell; (iii) reading repeatedly to clarify ideas and unifying each classification criteria.

Third, step 3: (i) filtering data based on codes, comparing the appearance of the code with the research questions to find out the link between the code and management accounting information; (ii) repeating this procedure several times to find out and forming links between factors.

\section{Results and Discussions}

We divide into two groups for the research:

i) The managers and enterprises: to know how the managers and enterprise will be influenced by preparing and using the management accounting information.

ii) Management accountant: to clarify the relationship between management accountant preparation and supply of management accounting information.

Research results for group 1 are revealed in Table 3.

Table 3. Results related to Managers and Enterprises

1. The manager has not noticed the importance of management accounting information in a decision- making.

- Director of firm 2: "I usually ask the accountant to submit reports monthly and I am most concerned about the income statement, knowing what the profits and losses of a firm. The decision is often based on speculation and personal experience".

- Director of firm 3 aid: "Most of our clients are traditional ones so I know all basic information, from produce according to order to receivable and payable accounts, I don't need more complex information".

- Director of firm 4: "In my opinion, with small-scale firms, the provided accounting information is enough. When my firm becomes a larger scale one, I would care of accounting information issue".

2. The managers who have knowledge and be trained in accounting, usually proactively require to be provided information more frequently, especially pay attention to forecasts or unusual problems.

To clarify this statement, we have compared director of firm 1 and director of firm 5, who have been trained in accounting with director of firm 3 who has been untrained in accounting:

For example:

- Accountant of firm 1: "My boss often criticizes that the accounting department has not given the warning information such as defective product, increasing price of inputs in the production process, etc. Accountants usually report periodically, after everything happened".

- Accountant of firm 5: "Directors regularly asked for information, many petty questions, and we often report unusual problems via email". 
- Director of firm 3: "I often ask for basic information at the end of each month such as cost, receivables, payable accounts".

- Accountant of firm 3: "Director rarely asked for information from accounting department, only report on receivable, payable and expenses accounts".

3. The managers who collect and analyze information by themselves for decision- making based on their experiences and memories.

This result is based on opinions of interviewees:

- Director of firm 2: "I regularly check and review all processes, from design to production and consumption. If unusual problems happen, I would ask for adjustment immediately".

- Director of firm 3: "I remember, record all basic information from import, export to receivable and payable accounts....".

- Director of firm 4: "I prepare estimates by myself for some key products because I know the price of materials and often sign long-term contracts with suppliers".

- Accountant of firm 4: "He goes to the pharmacy to find out by his personal experience".

- Accountant of firm 5: "He is a very talented man who has an excellent master degree in UK. He calculates and analyzes all information by himself. The accountant just does based on his requests on basic information".

4. The manager who spends a little time on administration and asks for a little of accounting information.

- Director of firm 3: "I have been distracted by a lot of work which does not belong to the company".

- Accountant of firm 3: "Director requires a little information from accountant. The report normally is on receivable and payables and expenditures accounts".

5. The scale of small businesses has limited to requirement and using of management accounting information.

This statement has reflected based on the opinions of the enterprises:

- Director of firm 4: "Enterprise has not assigned to each department because of small scale, everything is still in the control. When my enterprise gets larger scale, I will study the application".

- Accountant of firm 5: "My enterprise is small-scale one so I should not apply the complex accounting tools and methodology. There is no change in the supply of information in the near future".

6. The content of the information provided by the accountant is usually financial accounting information via periodically financial report. Management accounting Information is often as simple as sales, debts, cash flow or estimates reports (sales, production, expenditures, revenue) and segment reporting.

- Director of firm 1: "The company has made the reports on each kind of product, but only the report on production costs, not cover to the sales and administration costs".

- Accountant of firm 2: "We have made an income statement for each item and each region".

- Accountant of firm 3: "Accountant just makes weekly expenditure estimates, while receivable accounts are based on the customers, being out of control."

- Director of firm 5: "I calculate and plan for production and cash flow".

The administrator may use some analytical techniques of management accounting such as incremental analysis, CVP analysis, breakeven point analysis targeted profit or responsibility accounting.

- Director of firm 4: "I compare and analyze the preliminary differences between revenue and expenses based on the accountant's report. I calculate by myself to find out the breakeven point, especially for new product lines".

- Accountant of firm 1: "The Company has targeted for the production groups but has been limited because the groups only pay attention to quantity and forget product quality, which increases the number of damaged products". 
Research results for Group 2 are shown in Table 4.

Table 4. Results related to Management Accountants

1. The higher qualification an accountant gets, the more proactive in providing and processing information, information exploitation, especially, forecasting information.

- Accountant of firm 2, doctor in economics: "Based on the financial information of the enterprise, I analyze the information as report by goods, fluctuations in revenues ... If there is something abnormal, I will inform to the manager ".

- Accountant of firm 4, who have auditor certificate: "I proactively analyze the information, preparing the report by goods and regions to consult to the director. When urgent problem happens, I will inform verbally to the director ".

- Accountants of firms 1, 3 and 5: They mainly provide basic information such as monthly financial statements, receivable and payable accounts, revenue or other jobs required by their directors.

- Director of firm 3: "Accountant's firms rarely provide the necessary information to the director."

2. Management accountants are passive, do not to promote the role of providing information for managers:

- Director of firm 1: "I request accountants to create indicators system to control the enterprise's' costs, from the estimates and norms to report, but they have not perform. I am looking for an external consultant".

- Director of firm 3: "The management reports as report by goods, by region or information for decision-making are mainly created by my personal experience and not being advised by our ineffective accountant".

- Director of firm 2: "Accountants do not carry out estimates, only do the mathematics. Accountant only provides the basic information, mainly revenue, cash and finance statements"

- Accountant of firm 5: "Accountant just provides the basic information required by the director."

\section{Conclusion}

From the results, we found that the highlight issues on the management accounting information in SMEs in Vietnam as follows:

First, the importance of management accounting information in SMEs in Vietnam has not really taken seriously, from managers to management accountant.

Next, the contents of the accounting information provided to the managers are also very simple focusing on the financial accounting and basing on the framework of regulations.

Then, quality of management accounting information is governed by accounting knowledge, experience, spent time by managers and the qualification of management accountant.

Last, the role of management accounting information provided by accountant has not really supported to the management for decision-making. The decisions based mainly on managers' experience and memories.

In general, management accounting information has not promoted the role of the executive to make decision. There are three main reasons: (i) the managers are lack of management accounting knowledge, so they did not require information from accountants; (ii) the managers noticed the importance of information but the abilities of accountant is limited, they did had efficiency support to managers; (iii) the small size of businesses did not really draw much attention of managers for information.

To change this reality, managers and accountants need to change perceptions and attitudes about the role of management accounting information for the management, decision-making in the operation of enterprises. Managers need to have a correct understanding to be provided the information, the accountants need to have implementation tools to provide useful and suitable information for the managers. Equipping managers and accountant with knowledge of management accounting is an urgent issue today. This is the basis to provide training services of management accounting for manager and accountant. Establishing a management accounting system with modern tools is urgently required in college, training facilities to make accounting management to become an effective tool in the operation, control and decisions making and change the perception of stakeholders on management accounting. 


\section{References}

Abdel-Kader, M., \& Luther, R. (2008). The impact of firm characteristics on management accounting practices: A UK-based empirical analysis. The British Accounting Review, 40, 2-27. https://doi.org/10.1016/j.bar.2007.11.003

Al-Omiri, M., \& Drury, C. (2007). A survey of factors influencing the choice of product costing systems in UK organizations. Management Accounting Research, 18, 399-424. https://doi.org/10.1016/j.mar.2007.02.002

Chenhall, R.H. \& Langfield-Smith, K. (1998). The relationship between strategic priorities, management techniques and management accounting: an empirical investigation using a systems approach. Accounting, Organizations and Society, 23(3), 243-264. https://doi.org/10.1016/S0361-3682(97)00024-X

Demong, R. F., \& Croll, D. B. (1981). Cost accounting for the small business. American Journal of Small Business, 5 , 48-60.

Drury, C., Braund, S., Osborne, P., \& Tayles, M. (1993). A survey of management accounting practices in UK manufacturing companies. Chartered Association of Certified Accountants. UK.

Dinh, P. T. (2003). Improving accounting for costs at air transportation firms in Vietnam, $\mathrm{PhD}$ thesis, National Economics University.

El-Ebaishi, M., Karbhari, Y., \& Naser, K. (2003). Empirical evidence on the use of management accounting techniques in a sample of Saudi manufacturing companies. International Journal of Commerce and Management, 13, 74-101. https://doi.org/10.1108/eb047467

Firth, M. (1996). The diffusion of managerial accounting procedures in the People's Republic of China and the influence of foreign partnered joint ventures. Accounting, Organizations and Society, 21, 629-654. https://doi.org/10.1016/0361-3682(95)00039-9

Friedley, F. R. (1956). Cost studies for cost reductions. National Association of Accountants, 37(8), 972.

General Statistics Office of Vietnam. (2016). Statistical year book of Vietnam 2016. Finance Publishing House.

Ghosh, B. C., \& Chan, Y. K. (1997). Management accounting in Singapore-well in place? Managerial Auditing Journal, 12, 16-18. https://doi.org/10.1108/02686909710155966

Gunasekaran, A; Marri, H. B.; Yusuf, Y. Y. (1999). Managerial Auditing Journal, 14(6), 286-293. https://doi.org/10.1108/02686909910280217

Haibo, H. (2010). Primary Research of the Advantages and the Cost Control of the ABC \& EVA Integrated System. International Business Research, 3(3), 141-143. https://doi.org/10.5539/ibr.v3n3p141

Hopper, T., Koga, T., \& Goto, J. (1999). Cost accounting in small and medium sized Japanese companies: An $\begin{array}{lllll}\text { exploratory study. Accounting and Business Research, } & \text { 30, }\end{array}$ https://doi.org/10.1080/00014788.1999.9728925

Hoque, Z., \& James, W. (2000). Linking balanced scorecard measures to size and market factors: Impact on organizational performance. Journal of Management Accounting Research, 12, 1-12. https://doi.org/10.2308/jmar.2000.12.1.1

Hyv"onen, J. (2007). Strategy, performance measurement techniques and information technology of the firm and their links to organizational performance. Management Accounting Research, 18, 343-366. https://doi.org/10.1016/j.mar.2007.02.001

Jarvis, R., Kitching, J., Curran, J., \& Lightfoot, G. (2000). The use of quantitative and qualitative criteria in the measurement of performance in small firms. Journal of Small Business and Enterprise Development, 7, 123-134. https://doi.org/10.1108/EUM0000000006834

Joshi, P. L. (2001). The international diffusion of new management accounting practices: The case of India. Journal of International Accounting, Auditing and Taxation, 10, 85-109. https://doi.org/10.1016/S1061-9518(01)00037-4

Johnson, H. T., \& Kaplan, R. S. (1987). Relevance Lost: The Rise and fall of Management Accounting. Boston, Massachusetts: Harvard Business School Press.

Le, D. T. (2002). Management accounting and analysis cost at industrial firms in Vietnam. PhD thesis, Academy of Finance. 
Mac, T. T. H. (2007). Improving management accounting of cost at Thai Nguyen Steel firm. Master thesis, National Economics University.

Marriott, N., \& Marriott, P. (2000). Professional Accountants and the Development of a Management Accounting Service for the Small Firms: Barriers and Possibilities. Management Accounting Research, 11, 475-492. https://doi.org/10.1006/mare.2000.0142

McChlery, S., Meechan, L., \& Godfrey, A. D. (2004). Barriers and catalysts to sound financial management systems in small sized enterprises. Research Executive Summaries Series CIMA, 1.

Mitchell, F., \& Reid, G. C. (2000). Editorial problems, challenges and opportunities: The small business as a setting for management accounting research. Management Accounting Research, 11, 385-390. https://doi.org/10.1006/mare.2000.0152

Nandan, R. (2010). Management Accounting Needs of SMEs and the Role of Professional Accountants: A Renewed Research Agenda. Journal of Management Accounting Research, 8, 65-77.

Nguyen, V. T. (2013). Research in economics and business administration. National Economics University Press.

Phadoongsitthi, M. (2003). The role of management accounting in emerging economies: An empirical study of Thailand, Ph.D thesis, University of Maryland.

Pham, V. D. (1997). Content design and application of management accounting in enterprises in Vietnam, PhD thesis, Ho Chi Minh University of Economics.

Pham, Q. (2002). Designing management accounting reports and its application in Vietnam, PhD thesis, National Economics University.

Pham, T. T. (2007). Designing the model of management accounting in pharmaceutical firms in Vietnam, PhD thesis, National Economics University.

Scarbrough, P., Nanni, A. J., \& Sakurai, M. (1991). Japanese management accounting practices and the effects of assembly and process automation. Management Accounting Research, 2, 27-46. https://doi.org/10.1016/S1044-5005(91)70025-5

Shields, M. D., Chow, C. W., \& Kao, Y. (1991). Management accounting practices in the U.S. and Japan: Comparative survey findings and research implications. Journal of International Financial Management \&Accounting, 3, 61-77. https://doi.org/10.1111/j.1467-646X.1991.tb00091.x

Smith, R. D. (1962). Bugetary planning and control in a steel company. National Association of Accountants, 43(6), 5-16.

Sousa, S. D., Aspinwall, E. M., \& Rodrigues, A. G. (2006). Performance measures in English small and medium enterprises: Survey results benchmarking. An International Journal, 13, 120-134.

Tran, V. D. (2002). Management accounting and cost accounting in manufacturing firms in Vietnam, PhD thesis, Academy of Finance.

Tran, V. H. (2007). Management accounting of cost and cost manufactured in coal firms, PhD thesis, Academy of Finance.

Tran, T. H. M. (2003). Improving accounting for borrowing interests in Vietnamese firms, PhD thesis, University of Commerce.

University of Labor and Social Affairs. (2010). Management accounting textbook. Finance Publishing House.

Wijewardena, H., \& De Zoysa, A. (1999). A comparative analysis of management accounting practices in Australia and Japan: An empirical investigation. The International Journal of Accounting, 34, 49-70. https://doi.org/10.1016/S0020-7063(99)80003-X 